\section{AKUNTANSI SYARIAH DI INDONESIA PROSPEK DAN TANTANGANNYA DI MASA DEPAN}

\section{Nur Hasanah}

Fakultas Syari'ab dan Ilmu Hukum UIN Suska Riau

\section{Abstract}

Syariah accountancy in Indonesia, Prospect and it's Challenge in the future: As a result of the development of Islamic banks, there are a lot of preparations to be done such as from sociological perspective in which people tends to be usual in conservative banks; from the buman resources who have enough ability in an operational system of Islamic banks;from the softwares and hardwares to support the operational system of Islamic banks. One of the important softwares in Islamic banks is syariah or Islamic accountancy. The activity of syariah economy in the syariah financial institutions will not get maqasid al-syariah or the intention of legislation if the system of its accountancy is not based on syariah. The future of the syariah banks or other Islamic financial institutions will depend on the ability of their human resources in getting rid of the conventional accountancy systems. Those who engage in Islamic banks or Islamic financial institutions should have an understanding in syariah or Islamic accountancy since their skills will contribute the future of syariab or Islamic financial systems.

Keywords: Islamic Economi, Syari'ah Bank, Syari'ah Accountancy.

\section{Pendahuluan}

Dimulai sejak tahun 1970-an sistim ekonomi Islam mengalami kebangkitan kembali, yakni ditandai dengan lahirnya lembaga keuangan syariah baik yang berbentuk bank maupun non bank di beberapa negara baik yang penduduknya mayoritas Muslim maupun non Muslim. Di Indonesia sendiri, perkembangan ini menunujukkan tanda yang sangat berarti sejak sekitar awal tahun 1990-an, ditandai dengan lahirnya UU No. 7/1992 dan berdirinya PT. Bank Perkreditan Rakyat Syariah (BPRS) serta PT. Bank Muamalat Indonesia pada masa itu. Walaupun secara kuantitas pertumbuhan jumlah bank yang
Nurhasanah, Akuntansi Syariah di Indonesia...

beroperasi dengan dasar syariah ini tidak terlalu cepat, namun ada perkembangan yang menarik dan patut dicatat dari segi yuridis, yakni dengan lahirnya UU No.10 /1998 yang mengakomodir secara jauh lebih tegas dan lebih terbuka terhadap keberadaan bank syariah ini. Sudah barang tentu hal ini merupakan fenomena yang menggembirakan dan patut disyukuri karena pemerintah telah memberikan alternatif kepada masyarakat dalam melaksanakan apa yang oleh masyarakat diyakini benar sesuai dengan akidah mereka, apalagi masyarakat Indonesia sebagian besar beragama Islam.

Sebagai konsekwensi atas berdiri dan tumbuhnya bank-bank syariah ini, maka banyak sekali hal-hal yang harus dipersiapkan secara matang dan bijak, mulai dari sisi sosiologis masyarakat yang sudah lama terbiasa dengan sistem yang mengandunga unsur riba, sisi sumber daya manusia yang memahami dengan baik sistem operasi bank syariah, sampai dengan berbagai perangkat keras dan lunak untuk menunjang operasi bank tersebut, sehingga cita-cita pendirian dan pengoperasiannya bisa diharapkan tercapai secara optimal sesuai syari'ah dalam waktu yang wajar.

Salah satu perangkat yang sangat penting untuk dipersiapkan adalah perangkat lunak berupa akuntansi syariah. Sistem akuntansi ini secara konseptual berbeda dengan akuntansi konvensional yang selama ini sudah banyak digunakan. Sisi penting dari aspek akuntansi ini untuk segera dipersiapkan karena aspek ini akan secara tegas dapat membedakan sistem syari'ah dan konvensional pada konsep perhitungannya. Jika dipandang dari sisi kelembagaan, penerapan akuntansi syariah yang paling mendesak dipersiapkan dengan baik adalah di tingkat perbankan. Hal ini karena lembaga perbankan syari'ah berhubungan langsung dengan public yang menyangkut likuiditas uang. Sekalipun demikian perlu diupayakan juga pada tingkat yang lebih umum yang tidak terbatas pada lembaga keuangan saja.

Pada tingkatan pertama, akuntansi syariah selain memang sangat mendesak untuk kebutuhan yang tidak dapat ditunda lagi, telah mengalami kemajuan yang sangat pesat. Walaupun dengan usaha yang sangat melelahkan saat ini sudah ada conceptual frame work yang dituangkan dalam Statements of Financial Accountung No. 1 dan 2, 
AlFikra: Jurnal Iliah Keislaman, Vol. 8, No. 1, Januari-Juni 2009 dilengkapi dengan 10 Financil Accounting Standad. Karya ini dimotori oleh AAOIFI (Accounting and Auditing Organization for Islamic Financial Institution) di Bahrain, sudah dimulai perjuangan dan pengerjaannya sejak sekitar tahun 1990-an. Kerangka konseptual dan standar akuntansi versi Bahrain ini, walaupun belum sepenuhnya mendapat dukungan mutlak dari negara-negara yang memiliki perbankan syariah, setidaknya telah menjadi acuan di banyak negara dalam mengatasi kebutuhan akan akuntansi syariah. Indonesia sendiri sudah memanfaatkan, baik kerangka konseptual maupun standarnya sebagai acuan utama dalam menyusun standar akuntansi untuk perbankan syariah. Bangsa ini patut bersyukur karena pada tanggal 1 Mei 2002 Ikatan Akuntan Indonesia (IAI) telah mengeluarkan Pernyataan Standar Akuntansi Keuangan No. 59 (PSAK No. 59) tentang akuntansi perbankan syariah. Terbitnya PSAK No. 59 ini merupakan langkah maju bagi: pertama, IAI sendiri sebagai lembaga professional yang memiliki otoritas untuk menerbitkan standar akuntansi keuangan dan kedua, dunia perbankan syariah di Indonesia yang mulai eksis sejak tahun 1992.

Di tingkatan lain, untuk kebutuhan yang lebih luas, yakni industri di luar perbankan syariah, tampaknya perkembangan yang terjadi masih terbatas pada wacana konseptual yang belum mengerucut kearah terwujudnya standar baku yang dapat dijadikan acuan dalam pengoperasian sistem syari'ah di masa depan.

Melihat permasalahan diatas, maka makalah ini ditulis dalam rangka mengkaji prospek akuntansi syariah di Indonesia dan tantangannya di masa depan.

\section{Kerangka Konseptual Akuntansi Berdasarkan Syariah.}

Ada beberapa definisi akuntansi modern yang dapat disajikan dalam makalah ini, antara lain menurut Littleton, tujuan utama dari akuntansi adalah untuk melaksanakan perhitungan periodik antara biaya (usaha) dan hasil (prestasi). Konsep ini merupakan inti dari teori
Nurhasanah, Akuntansi Syari'ah di Indonesia...

akuntansi dan merupakan ukuran yang dijadikan sebagai rujukan dalam mempelajari akuntansi ${ }^{1}$

Dalam APB (Accounting Principle Board) Statement No. 4, akuntansi didefinisikan sebagai berikut: "Akuntansi adalah suatu kegiatan jasa. Fungsinya kuantitatif yakni memberikan informasi kuantitatif, umumnya dalam ukuran uang, mengenai suatu badan ekonomi yang dimaksudkan untuk digunakan dalam pengambilan keputusan ekonomi, yang digunakan dalam memilih diantara beberapa alternative."2

Sementara itu Drs. Mohammad, MAg, seperti dikutip dari AICPA (American Institute of Certified public Accountant) mendefinisikan sebagai berikut; akuntansi adalah seni pencatatan, penggolongan dan pengikhtisaran dengan cara tertentu dan dalam ukuran moneter, transaksi, dan kejadian-kejadian yang umumnya bersifat keuangan dan termasuk penafsiran hasil-hasilnya. ${ }^{3}$

Sedangkan Akuntansi Syariah, menurut Iwan Tri Yuwono dan Gaffikin, merupakan salah satu upaya mendekonstruksi akuntansi modern kedalam bentuk yang humanis dan syarat nilai. Tujuan diciptakannya akuntansi syariah adalah terciptanya peradaban bisnis dengan wawasan humanis, emansipatoris, transendental, dan teologikal. ${ }^{4}$

Lebih jauh Triyuwono menguraikan sifat-sifat tersebut sebagai berikut: Nilai humanis akuntansi syariah adalah bahwa akuntansi yang dibentuk ini ditujukan untuk memanusiakan manusia, atau mengembalikan manusia pada fitrahnya yang suci. Sebab menurut penelitian Morgan, diketahui bahwa praktek akuntansi telah mengakibatkan manusia menjadi less bumane. Sifat humanis akuntansi diharapkan dapat mendorong perilaku manusia itu sendiri, sehingga hlm. 27

${ }^{1}$ Littleton, A.C, Social Accounting, (London: George Allen \& Alwin, 1974),

2 Sofyan S. Harahap, Akuntansi Islam, (Jakarta: Bumi Aksara, 1997), hlm. 40

${ }_{3}$ Muhammad, Pengantar Akuntansi Syari'ah edisi 2, (Jakarta: Salemba Empat, 2005), hlm. 67

4 Iwan Triyuwono dan MJR. Grafikkin, Shariate Accounting An Ethical Instruction of Accounting Knowledge, (New York City: T.P., 1996), hlm. 6. 
AlFikra: Jurnal Iliah Keislaman, Vol. 8, No. 1, Januari-Juni 2009

manusia semakin kuat kesadaran dirinya tentang hakikatnya. Melalui kesadaran diri tentang hakikat manusia ini merupakan landasan bagi manusia dalam memberi nilai emansipatoris pada akuntansi syariah. ${ }^{5}$ Sifat ini berarti bahwa tidak lagi berlaku bentuk dominasi atau penindasan dari satu pihak ke pihak lain. Dengan kata lain, informasi yang diberikan oleh akuntansi syariah adalah berupa pembebasan dan tertuju pada semua pihak serta tidak menyepelekan pihak lain, atau akuntansi syariah akan berdiri pada posisi yang adil.

Oleh karena akuntansi syariah dibangun berdasarkan syariah Islam, maka nilai transendental akuntansi syariah terlihat jelas. Hal ini merupakan indikasi yang kuat bahwa akuntansi syariah tidak sematamata menjadi instrumen bisnis yang bersifat profane, tetapi juga sebagai instrumen yang melintas batas dunia (transcendence). Dengan demikian, yang selama ini akuntansi dikenal sebagai alat pertanggung jawaban kepada pemilik perusahaan, maka akuntansi syariah adalah lebih dari pada itu, yaitu pertanggung jawaban kepada stockholders dan Tuhan. Dengan sifat ini dalam melakukan praktek bisnis dan akuntansi maka seseorang yang terlibat akan selalu menggunakan atau tunduk dan pasrah terhadap kehendak Tuhan. Nilai semacam inilah yang dimaksud dengan teologikal. Artinya praktek akuntansi syariah akan mengantarkan pelakunya secara riil teraktualisasi dalam bentuk kegiatan menciptakan dan menyebarkan kesejahteraan bagi seluruh alam.

Dasar munculnya akuntansi syariah adalah al-Quran surat Albaqarah; 282 yang menyatakan bahwa;

"Hai orang-orang yang beriman, apabila kamu bermuamalah tidak secara tunai untuk waktu yang ditentukan hendaklah seorang penulis diantara kamu menuliskannya dengan benar. Dan janganlah penulis enggan menuliskannya sebagaimna Allah telah mengajarkannya, maka hendaklah ia menulis, dan hendaklah orang berutang itu mengimlakkan apa

5 Gareth Morgan, Accounting as Reality Construction: Towards a New Epistemology for Accounting Practice, Accounting, Organization and Society, (t.t.: t.p., 1988), hlm. 477.
Nurhasanah, Akuntansi Syariah di Indonesia...

yang ditulis itu, dan hendaklah ia bertaqwa kepada Allah dan janganlah ia mengurangi sedikitpun dari pada utangnya. Jika yang berutang itu orang yang lemah akal atau lemah keadaannya atau dia sendiri tidak mampu mengimlakkan, maka hendaklah wakilnya mengimlakkan dengan jujur dan persaksikanlah dengan dua orang saksi dari orang laki-laki diantara kamu. Jika tak ada dua orang laki-laki maka bolehlah seorang laki-laki dan dua orang perempuan dari saksi yang kamu ridloi, supaya jika seorang lupa maka seorang lagi mengingatkannya. Janganlah saksi itu enggan memberi keterangan apabila mereka dipanggil, dan janganlah kamu jemu menuliskan utang itu, baik kecil maupun besar sampai waktu membayarnya. Yang demikian itu lebih adil disisi Allah dan lebih dapat menguatkan persaksian dan lebih dekat kepada tidak menimbulkan keraguan (Tulislah muamalahmu itu) kecuali jika muamalahmu itu perdagangan tunai yang kamu jalankan diantara kamu, maka tak ada dosa bagi kamu berjual beli, dan janganlah penulis dan saksi saling sulit menyulitkan. Jika kamu lakukan yang demikian itu, maka sesungguhnya hal itu adalah suatu kefasikan pada dirimu. Dan bertakwalah kepada Allah. Allah mengajarmu dan Allah Maha Mengetahui segala sesuatu. (QS.Albaqarah: 282).

Dari ayat ini dapat diketahui bahwa sejak munculnya peradaban Islam telah ada perintah untuk melakukan pencatatan yang penekanannya adalah untuk tujuan kebenaran, kepastian, keterbukaan, keadilan antara dua pihak yang mempunyai hubungan muamalah.

Konsep Islam dan hakekat akuntansi mempunyai persamaan yang searah dan telah terbukti bahwa akuntansi ada dalam Islam dan bahkan memberikan andil dalam perkembangannya (Meidawati,1998). Hal ini dapat dilihat bahwa:

1. Yang dicatat akuntansi adalah transaksi (muamalah).

2. Dasar pencatatan trasaksi adalah bukti (evidence) seperti faktur, cek, kwitansi.

3. Bukti yang menjadi dasar pencatatan akan diklasifikasikan secara teratur dengan menggunakan aturan umum yang disebut Standar Akuntansi Keuangan. 
AlFikra: Jurnal Iliah Keislaman, Vol. 8, No. 1, Januari-Juni 2009

4. Untuk mencapai tingkat kepercayaan yang lebih tinggi, laporan keuangan yang dihasilkan harus diperiksa oleh pihak yang independent. ${ }^{6}$

Dari hal tersebut, proses pencatatan sampai tersusunnya laporan keuangan dalam akuntansi harus dilakukan dengan benar sehingga informasi yang dihasilkan dapat digunakan oleh pihak umum.Terlihat bahwa sistim akuntansi harus menjaga output yang dihasilkan tetap dalam sifat kebenaran, keadilan dan kejujuran (objectivity) sebagaimana halnya hakekat dan keinginan dalam ajaran Islam.

Menurut M. Akhyar Adnan, ada tiga dimensi dalam konsep akuntansi syariah yang saling berhubungan, yaitu ;

1. Mencari keridhoan Allah sebagai tujuan utama dalam menentukan keadilan sosio-ekonomi

2. Merealisasikan keuntungan bagi masyarakat, yaitu dengan memenuhi kewajiban kepada masyarakat

3. Mengejar kepentingan pribadi, yaitu memenuhi kebutuhan sendiri. ${ }^{7}$

Pemenuhan ketiga bagian bentuk aktivitas ini dipandang sebagai bagian dari ibadah. Oleh karenanya bagi seorang muslim melakukan kegiatan akuntansi yang benar dalam rangka merealisasikan tiga dimensi dan aktifitas di atas diyakini sebagai suatu aktivitas ibadah. Ketiga dimensi itu saling berhubungan untuk memenuhi kewajiban kepada Tuhan, masyarakat dan hak individu, dengan berdasarkan prinsip syariah. Berdasarkan paparan yang ada, maka secara visual kerangka konseptual akuntansi yang berdasarkan syariah dapat digambarkan sebagai berikut;

Meidwati, "Akuntansi Zakat dan Pengelolaannya di Perusahaan", Jurnal Akuntansi dan Auditing Indonesia, Vol.2, 1998. hlm. 201.

7 M. Akhyar Adnan, Akuntansi Syariah Arah, Prospek dan Tantangannya, Yogyakarta: UII Press, 2005), hlm. 70
Nurhasanah, Akuntansi Syariah di Indonesia..

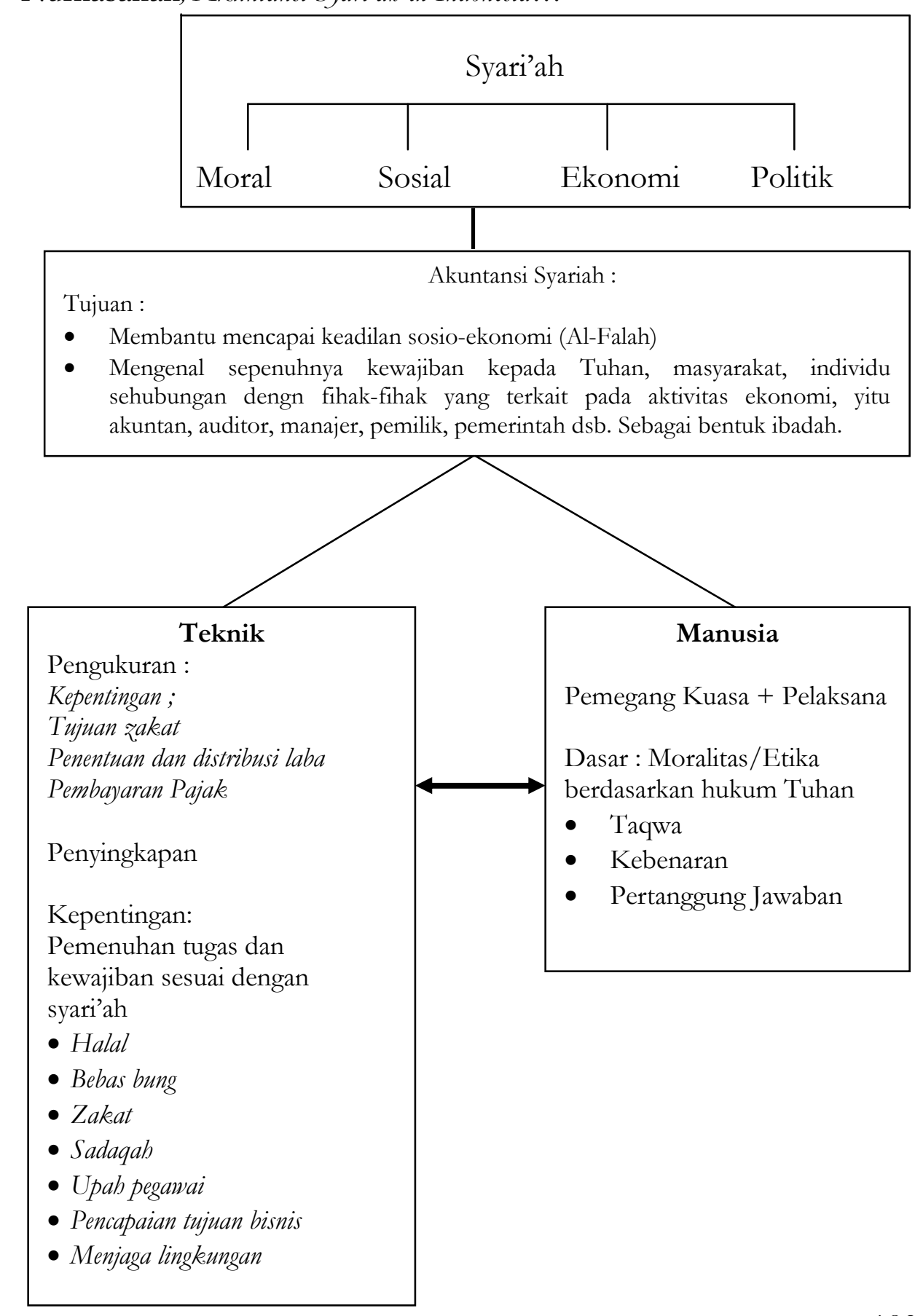


AlFikra: Jurnal Iliah Keislaman, Vol. 8, No. 1, Januari-Juni 2009

Berdasarkan gambar diatas dapat dilihat bahwa akuntansi syariah akan mencapai tujuan yang lebih luas tentang keadilan sosio-ekonomi (alfalah) dan mengakui bentuk ibadah. Prinsip-prinsip ini menunjukkan pada baik aspek teknis maupun kemanusiaan yang harus diturunkan dari syariah. Aspek teknis dalam akuntansi syariah adalah menunjuk pada konstruk akuntansi yang berhubungan dengan otoritas dan pelaksanaannya. Jelasnya masalah konstruk berhubungan dengan pengukuran dan penyingkapan, prinsip-prinsip sebagai berikut : zakat, bebas bunga, transaksi bisnis yang dihalalkan dalam hukum Islam, harus diyakini.

Sedangkan kerangka akuntansi yang berhubungan dengan masalah otoritas dan pelaksana, didasarkan pada prinsip-prinsip seperti taqwa, kebenaran dan pertanggung jawaban yang merupakan pondasi dasar yang akan mempengaruhi nilai-nilai akuntan muslim dan manajer dalam melakukan aktivitasnya. Secara ringkas hal tersebut dapat dilihat dalam tabel berikut :

\begin{tabular}{|l|l|}
\hline Ketaqwaan & $\begin{array}{l}\text { Mengakui bahwa Allah adalah Penguasa Tertinggi } \\
\text { Tuhan melihat setiap gerak yang akan dinilai pada hari } \\
\text { Pembalasan } \\
\text { Dapat membedakan yang benar dan yang salah } \\
\text { Mendapatkan bimbingan dari Allah dalam } \\
\text { pengambilan keputusan } \\
\text { Mencari barakah (Kemurahan Allah) }\end{array}$ \\
\hline Kebenaran & $\begin{array}{l}\text { Visi keberhasilan dan kegagalan yang meluas ke dunia, } \\
\text { yaitu mencapai Maslahah } \\
\text { Memperbaiki hubungan baik dengan Allah (Hablun } \\
\text { min'Allah) dan hubungan dengan manusia (Hablun } \\
\text { min an'nas) }\end{array}$ \\
\hline $\begin{array}{l}\text { Pertanggung } \\
\text { Jawaban }\end{array}$ & $\begin{array}{l}\text { Superioritas } \\
\text { Amanah } \\
\text { Mengakui bahwa kerja adalah ibadah yang selalu } \\
\text { dikatakan dengan norma dan nilai "langit" } \\
\text { Mengakui bahwa kerja adalah amal sholih, yang }\end{array}$ \\
\hline
\end{tabular}

Nurhasanah, Akuntansi Syari'ah di Indonesia...

\begin{tabular}{|l|l|}
\hline merupakan kunci untuk mencapai keberhasilan di \\
dunia dan akhirat (al-falah) \\
Merealisasikan fungsi manusia sebagai khalifah di \\
dunia dan bertanggung jawab atas perbuatannya \\
Berbuat adil kepada semua ciptaan Allah, bukan hanya \\
pada manusia (ihsan)
\end{tabular}

Perbedaan antara akuntansi konvensional dengan akuntansi syariah tidak hanya pada tujuannya saja namum juga pada prinsipprinsip dasarnya. Untuk lebih jelasnya berikut ini diberikan ringkasan perbedaan prinsip yang melandasi akuntansi syariah dan konvensional.

\begin{tabular}{|l|l|l|}
\hline & $\begin{array}{l}\text { Akuntansi } \\
\text { Konvensional }\end{array}$ & Akuntansi Syari'ah \\
\hline Postulat Entitas & $\begin{array}{l}\text { Pemisahan antara bisnis } \\
\text { dan pemilik }\end{array}$ & $\begin{array}{l}\text { Entitas didasarkan } \\
\text { pada bagi hasil. }\end{array}$ \\
\hline $\begin{array}{l}\text { Postulat Going- } \\
\text { Concern }\end{array}$ & $\begin{array}{l}\text { Kelangsungan bisnis } \\
\text { secara terus menerus, } \\
\text { yaitu didasarkan pada } \\
\text { realisasi keberadaan } \\
\text { asset. }\end{array}$ & $\begin{array}{l}\text { Kelangsungan usaha } \\
\text { tergantung pada } \\
\text { persetujuan kontrak } \\
\text { antara kelompok } \\
\text { yang terlibat aktivitas } \\
\text { bagi hasil. }\end{array}$ \\
\hline $\begin{array}{l}\text { Postulat Periode } \\
\text { Akuntansi }\end{array}$ & $\begin{array}{l}\text { Tidak dapat menunggu } \\
\text { sampai akhir kehidupan } \\
\text { perusahaan dengan } \\
\text { mengukur keberhasilan } \\
\text { aktivitas perusahaan }\end{array}$ & $\begin{array}{l}\text { Setiap tahun dikenai } \\
\text { zakat, kecuali untuk } \\
\text { produk pertanian } \\
\text { yang dihitung setiap } \\
\text { panen. }\end{array}$ \\
\hline $\begin{array}{l}\text { Postulat Unit } \\
\text { Pengukuran }\end{array}$ & Nilai uang & $\begin{array}{l}\text { Kuantitas nilai pasar } \\
\text { digunakan untuk } \\
\text { menentukan zakat } \\
\text { binatang, hasil } \\
\text { pertanian dan emas. }\end{array}$ \\
\hline $\begin{array}{l}\text { Prinsip } \\
\text { Penyingkapan }\end{array}$ & $\begin{array}{l}\text { Menunjukkan } \\
\text { pertujuan untuk } \\
\text { pengambilan keputusan han dan }\end{array}$ \\
\hline
\end{tabular}


AlFikra: Jurnal Iliah Keislaman, Vol. 8, No. 1, Januari-Juni 2009

\begin{tabular}{|c|c|c|}
\hline Penuh & & $\begin{array}{l}\text { keajiban kepada } \\
\text { Allah, masyarakat } \\
\text { dan individu. }\end{array}$ \\
\hline $\begin{array}{l}\text { Prinsip } \\
\text { Obyektivitas }\end{array}$ & $\begin{array}{l}\text { Reliabilitas pengukuran } \\
\text { digunakan dengan dasar } \\
\text { bias personal. }\end{array}$ & $\begin{array}{l}\text { Berhubungan erat } \\
\text { dengan konsep } \\
\text { ketaqwaan, yaitu } \\
\text { pengeluaran materi } \\
\text { maupun non materi } \\
\text { untuk memenuhi } \\
\text { kewajiban. }\end{array}$ \\
\hline Prinsip Materi & $\begin{array}{l}\text { Dihubungkan dengan } \\
\text { kepentingan relatif } \\
\text { mengenai informasi } \\
\text { pembuatan keputusan. }\end{array}$ & $\begin{array}{l}\text { Berhubungan dengan } \\
\text { pengukuran dan } \\
\text { pemenuhan tugas / } \\
\text { kewajiban kepada } \\
\text { Allah, masyarakat } \\
\text { dan individu. }\end{array}$ \\
\hline $\begin{array}{l}\text { Prinsip } \\
\text { Konsisitensi }\end{array}$ & $\begin{array}{l}\text { Dicatat dan di laporkan } \\
\text { menurut pola GAAP }\end{array}$ & $\begin{array}{l}\text { Dicatat dan } \\
\text { dilaporkan secara } \\
\text { konsisten sesuai } \\
\text { dengan prinsip yang } \\
\text { dijabarkan oleh } \\
\text { syari'ah. }\end{array}$ \\
\hline $\begin{array}{l}\text { Prinsip } \\
\text { Konservatisme }\end{array}$ & $\begin{array}{l}\text { Pemilihan teknik } \\
\text { akuntansi yang sedikit } \\
\text { pengaruhnya terhadap } \\
\text { pemilik. }\end{array}$ & $\begin{array}{l}\text { Pemilihan teknik } \\
\text { akutansi dengan } \\
\text { memperhatikan } \\
\text { dampak baiknya } \\
\text { terhadap masyarakat. }\end{array}$ \\
\hline
\end{tabular}

Realitas yang diciptakan oleh akuntansi konvensional diatas adalah realitas yang tidak ideal. Yang diinginkan adalah realitas yang sarat dengan nilai-nilai etika (etika dalam pengertian menyeluruh), yaitu realitas yang didalamnya terdapat jaring-jaring kuasa illahi yang akan mempengaruhi pengguna informasi akuntansi untuk selalu bertindak etis, baik kepada sesama manusia, kepada lingkungan alam, maupun pada Tuhan sendiri.
Nurhasanah, Akuntansi Syari'ab di Indonesia...

Untuk keperluan ini dibutuhkan akuntansi yang memang kondusif yaitu akuntansi syariah. Informasi akuntansi syariah diekspektasikan memberikan informasi yang lebih adil bila dibandingkan dengan akuntansi konvensional. Karena dalam proses konstruksinya, akuntansi syariah berdasarkan pada asumsi hakikat diri manusia sejati dan pemahaman aspek ontology yang lebih lengkap bila dibandingkan dengan akuntansi konvensional.

Dalam konstruksi akuntansi syariah, hakikat diri manusia dan pandangan ontologi adalah dua hal yang sangat penting. Karena, hakikat tentang diri akan mempengaruhi cara pandang seseorang terhadap realitas yang ia hadapi dan akan dikonstruksi dengan mempersepsikan diri sendiri sebagai homo economicus, misalnya akan mengantarkan orang tersebut untuk melihat realitas dari sudut pandang ekonomi (materi) saja. Akibatnya tindakan-tindakan yang dilakukan cenderung mengarah pada pembentukan realitas yang berkonsentrasi pada ekonomi.

Tentu hal ini sangat berbeda bila seseorang mempersepsikan dirinya sabagai khalifatullah fil ardhi (QS 2:30). Dengan persepsi semacam ini, ia secara etis mempunyai tanggung jawab untuk menyebarkan rahmat bagi seluruh mahluk (QS 21:107) dengan jalan amar ma'ruf nabi munkar (QS 3:110). Pencapaian akan hakikat diri ini dapat dilakukan dengan proses dialektik dalam dirinya sendiri (internal dialectic process of self) yang melibatkan akal dan kalbunya. Bila ia telah mencapai dan menemukan hakikat dirinya, maka ia dapat menggunakan konsep khalifatullah fil ardhi sebagai perspektif untuk melihat dan membangun kembali realitas-realitas sosial dalam lingkungnnya. Dan dengan cara yang sama ia dapat memperoleh kesadaran ontologisme, yaitu suatu kesadaran atau pengertian yang menyatakan bahwa realitas sosial sebetulnya adalah kreasi manusia semata, realitas yang lekat dengan nilai-nilai yag dimiliki manusia itu sendiri, dan dengan demikian juga akan terlepas dengan nilai-nilai etika.

Dengan asumsi ontologisme semacam itu seorang akuntan tidak hanya diminta secara kritis melihat dan mengerti hubungn antara akuntan itu sendiri dengan apa yang harus dia pertanggung jawabkan, 
AlFikra: Jurnal Iliah Keislaman, Vol. 8, No. 1, Januari-Juni 2009

tetapi juga dituntut akuntansi macam apa yang harus di ciptakan dan bagaimana menciptakannya. Untuk menjawab pertanyaan-pertanyaan ini, seorang akuntan, dengan perspektif khalifatullah yang dimilikinya akan merujuk pada ayat QS 2; 282 seperti yang telah disebutkan diatas.

Ayat tersebut bisa dijadikan acuan untuk merefleksikan potensi nilai-nilai keadilan yang dimilikinya dalam bentuk tindakan nyata. Kata "dengan adil" atau "keadilan illahi" dalam ayat tersebut diatas, pada dasarnya mengandung tiga nilai dasar, yaitu tauhid dan islam dalam arti penyerahan diri dan ketundukan kepada Allah, dan keadilan dalam arti keyakinan bahwa segala perbuatan manusia kelak akan dinilai oleh Allah. Jadi dengan melihat unsur yang terkandung didalamnya ini, adil tidak terlepas dari nilai-nilai etika atau moralitas yang tidak lain adalah wahyu atau hukum-hukum Allah itu sendiri.

Dalam konteks akuntansi, seorang akuntan secara normatif menjadikan nilai "keadilan illahi" sebagai dasar pijakan dalam berinteraksi dan mengkonstruksi realitas sosial. Ini berarti bahwa akuntansi sebagai sebuah disiplin atau praktek tidak dapat berdiri sendiri, artinya bahwa akuntansi selalu terikat pada realitas sosial dimana akuntansi ini dipraktekkan. Hal ini karena akuntansi dikiaskan sebagai cermin yang digunakan untuk merefleksikan realitas sosial. Dan perlu diketahui bahwa cermin itu sendiri juga adalah produk dari nilai-nilai ideologis dimana cermin itu dibuat. ${ }^{8}$

Pernyataan ini juga mempunyai makna bahwa "keadilan illahi" harus terkandung dalam realitas sosial dan akuntansi, mengapa demikian? Karena jika akuntansi dikonstruksi yang kompatibel dengan nilai "keadilan illahi" maka informasi akuntansi yang direfleksikan dari realitas sosial yang dibangun dengan nilai "keadaan illahi" akan terbias dan terdistorsi oleh nilai ideologis yang digunakan untuk mengkonstruksi bangunan akuntansi itu. Tentang hal ini Dillard mengisyaratkan, persepsi kita tentang "realitas" adalah seperti pada saat kita menatap permukaan cermin, kita hanya dapat melihat apa

8 R.I, Tricker, Research in Accounting, (Glasgow: University of Glasgow Press, 1978), hlm. 8.
Nurhasanah, Akuntansi Syari'ah di Indonesia...

yang direfleksikan oleh cermin itu pada kita. Permukaan cermin yang berbeda (karena kerangka ideology yang berbeda) akan merefleksikan realitas yang berbeda pula. ${ }^{9}$

Dengan demikian semakin jelas bahwa akuntansi yang dikonstruk dengan dasar ideologi yang berbeda akan merefleksikan realitas yang sama dengan bentuk yang berbeda. Keadaan ini akan menjadi semakin krusial ketika hasil refleksi tersebut, yaitu informasi akuntansi kemudian dikonsumsi oleh orang lain yang pada akhirnya akan membentuk realitas-realitas baru.

Konsekwensi ontologis yang harus disadari oleh akuntan adalah bahwa ia secara kritis harus mampu membebaskan manusia dari realitas semu beserta jaringan-jaringan kuasanya, untuk kemudian memberikan realitas alternatif dengan seperangkat jaringan-jaringan kuasa illahi yang mengikat manusia dalam kehidupan sehari-hari. Dengan cara demikian, realitas alternatif diharapkan akan dapat membangkitkan kesadaran diri (self consciosness) secara penuh akan kepatuhan dan ketundukan seseorang pada kuasa illahi. Dan dengan kesadaran ini pula, ia akan selalu merasakan kehadiran Tuhan dalam dimensi waktu dan tempat dimana ia berada. Jadi dengan asas keadilan illahi, reaitas sosial yang dikonstruk mengandung nilai tauhid dan ketundukan pada jaringan-jaringan kuasa illahi, yang semuanya dilakukan dengan perspektif khalifatulah fil ardhi, yaitu cara pandang yang sadar akan tanggung jawab kelak dikemudian hari dihadapan Allah SW'T.

Dalam konteks makalah ini akuntansi syariah diharapkan mampu memberikan informasi yang dapat memicu terciptanya realitas ideal yang didalamnya tersebar jaringan kuasa illahi yang menghantarkan manusia pada kesadaran diri sejati. Pada akhirnya berdasarkan hal-hal diatas maka peran akuntan muslim diantaranya adalah sebagai berikut:

1. Diilhami dengan pandangan dunia tentang tauhid, tidak ant laba atau anti dunia, tetapi suatu visi keberhasilan dan

${ }^{9} \mathrm{~F}$ Jesse Dillard, Accounting as Critical Social Science, Accounting Auditing Accountability Journal, 1991, hlm. 9 . 
AlFikra: Jurnal Iliah Keislaman, Vol. 8, No. 1, Januari-Juni 2009 kegagalan yang mencakup pada dimensi waktu yang lebih luas, yaitu dunia dan akhirat.

2. Pertanggung jawaban tidak hanya kepada pimpinan tetapi bertanggung jawab kepada Tuhan, karena manusia hanya sekedar hamba-Nya dengan tujuan untuk mewujudkan keadilan sosio ekonomi di dunia dan akhirat.

3. Hubungan - membutuhkan terciptanya hubungan baik antara pimpinan tetapi juga kepada pengikut, dan juga hubungan dengan Tuhan dengan memenuhi semua kewajiban keagamaannya.

4. Motivasi memberikan pelayanan yang terbaik dalam aktivitas akuntansinya, seperti amanah, ibadah, amal salih, yang kesemuanya ditujukan untuk mencapai kemenangan (al-falah) di dunia maupun di akhiat.

\section{Prospek dan Tantangan Akuntansi Syariah di Indonesia}

Seiring dengan bangkitnya gairah umat Islam untuk kembali ke khittahnya, yaitu menjadikan Alqur'an sebagai pedoman yang paling utama dalam menjalankan kehidupan dunia dan seperti dituntut oleh Alqur'an sendiri dalam Surat al-Baqarah $(2: 208)$, yang artinya: "Wahai orang-orang yang beriman, masuklah kamu ke dalam Islam secara menyeluruh ... ", maka sejak sekitar beberapa dekade belakangan ini terlihat semangat yang menggembirakan, manakala banyak kalangan Muslim mulai mengangkat wacana muamalah Islami, khususnya dalam bidang ekonomi. Lebih menggembirakan lagi, bahwa wacana ini kemudian diikuti dengan implementasi nyata, misalnya dalam bentuk pendirian lembaga keuangan Islam, seperti perbankan, takaful, reksadana Islami, dan lain sebagainya.

Sebagaimana diketahui bank syariah pertama lahir pada tahun 1991 dan mulai beroperasi resmi pada 1 Mei 1992. Keberadaan bank syariah ini setelah beberapa tahun kemudian disambut hangat dengan lahirnya beberapa bank lain seperti Bank syariah Mandiri, bank unit syariah dibawah bank konvensional, seperti BNI Syariah, Bank IFI Syariah, BRI Syariah, Bukopin Syariah dan beberapa bank lain yang
Nurhasanah, Akuntansi Syari'ah di Indonesia...

ingin membuka window syariah. Salah satu faktor pendorong lahirnya bank-bank ini mungkin juga telah dikeluarkannya Undang-undang No. 10 tahun 1998 sebagai perubahan atas Undang-Undang No. 7 tahun 1992 tentang perbankan, serta dikeluarkannya fatwa keharaman bunga bank oleh Majelis Ulama Indonesia (MUI) tahun 2003.

Dalam Undang-undang No. 10 tahun 1998 telah tercakup hal-hal yang berkaitan dengan perbankan syariah, dimana disebutkan dalam pasal 1 pengertian Bank Umum adalah bank yang melaksanakan kegiatan usaha secara konvensional dan atau "berdasarkan prinsip usaha syariah" yang dalam kegiatannya memberikan jasa dalam lalu lintas pembayaran. Sedangkan yang dimaksud dengan prinsip syariah dijelaskan pada pasal 1 butir 13 Undang-Undang tersebut sebagai berikut;

"Prinsip Syariah adalah aturan perjanjian berdasarkan hukum Islam antara bank dan pihak lain untuk penyimpanan dana dan atau pembiayaan kegiatan usaha, atau kegiatan lainnya yang dinyatakan sesuai dengan syariah, antara lain pembiayaan berdasarkan prinsip bagi hasil (mudharabah), pembiayaan berdasarkan prinsip penyertaan modal (musyarakah), prinsip jul beli barang dengan memperoleh keuntungan (murababab), atau pembiayaan barang modal berdasarkan prinsip sewa murni tanpa pilihan (jarah) atau dengan adanya pilihan pemindahan kepemilikan atas barang yang disewa dari pihak bank oleh ihak lain (ijarah wa iqtina). Sehingga dengan adanya Undang-Undang ini semakin bermunculan bank-bank syariah, BPR Syariah maupun unit usaha syariah di Indonesia."

Menurut data Bank Indonesia, sampai dengan bulan April tahun 2009 jumlah bank yang melaksanakan kegiatan usaha berdasarkan prinsip syariah mengalami peningkatan yang tajam.Di awal tahun 2009 terdapat 5 (lima ) Bank Umum Syariah (BUS), 25 Unit Usaha Syariah (UUS) dan 133 Bank Pembiayaan Rakyat Syariah (BPRS). Sejalan dengan hal tersebut, jaringan kantor Bank Syariah juga menunjukkan peningkatan menjadi 642 kantor, jumlah kantor untuk Unit Usaha Syariah sebanyak 253 dan jumlah kantor untuk Bank Pembiayaan 
AlFikra: Jurnal Iliah Keislaman, Vol. 8, No. 1, Januari-Juni 2009 Syariah sebanyak 209.Sehingga secara keseluruhan jumlah kantor untuk layanan syariah sebanyak 1104. (Tabel).

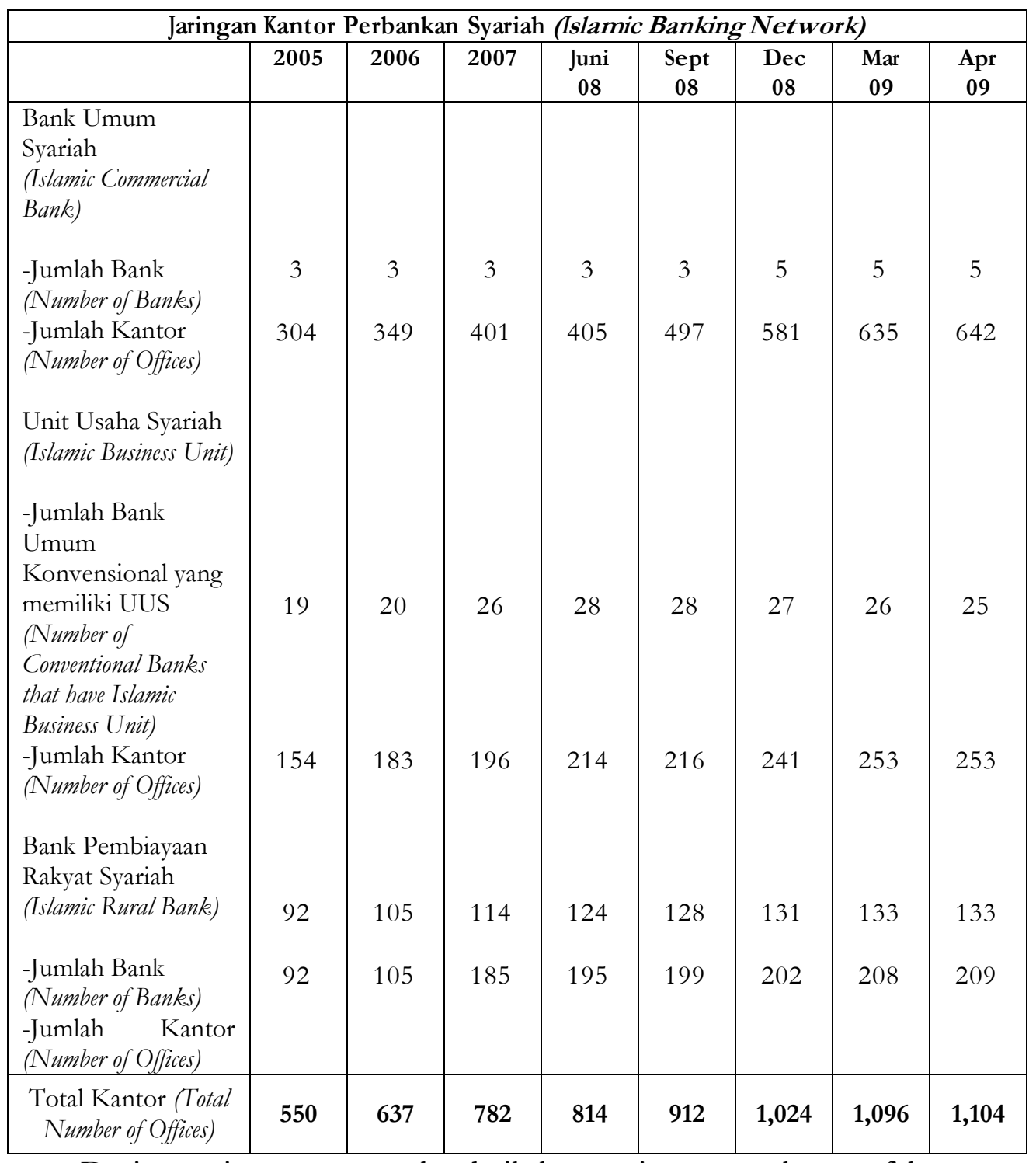

Dari antusiasme masyarakat baik karena iman atau karena faktor ekonomi diramalkan pangsa dan peran bank syariah akan semakin meningkat. Lebih-lebih karena Bank Syariah telah terbukti memiliki 192
Nurhasanah, Akuntansi Syari'ah di Indonesia...

berbagai keunggulan dalam mengatasi dampak krisis ekonomi yang baru lalu serta mempunyai potensi pasar yang cukup besar, mengingat mayoritas penduduk Indonesia adalah muslim yaitu sekitar $85 \%$ dari 220 juta penduduk Indonesia dan masih banyak di kalangan umat Islam yang enggan berhubungan dengan pihak bank yang menggunakan sistem bunga.

Implementasi berbagai lembaga ekonomi dan keuangan syariah ini, ternyata membawa sejumlah implikasi lanjutan, diantaranya adalah persoalan yang berkaitan dengan akuntansi. Sejumlah pertanyaan mendasar muncul, ketika disadari bahwa pola operasi lembaga ekonomi dan keuangan syariah ini terdapat sejumlah perbedaan fundamental dibandingkan dengan lembaga sejenis yang dilakukan secara konvensinal, sehigga perlu adanya penyempurnaan akuntansi konvensional bilamana dilakukan dalam lembaga ekonomi dan keuangan syariah.

Dalam perkembangannya sedikit demi sedikit pertanyaan itu mulai dijawab oleh Bank Indonesia dengan menerbitkan PSAK No 59 tentang Standar Akuntansi perbankan Syariah Indonesia. Terlepas dari kualitas dan kesempurnaannya, kesedian BI yang dibantu oleh Ikatan Akuntansi Indonesia (IAI) dalam menerbitkan PSAK 59 ini perlu kita kaji dan kita sokong sepenuhnya. Karena standar ini sangat perlu untuk mempercepat perkembangan bank syariah di negeri kita. Memang standar ini banyak mengadopsi kerangka dan standar yang dikeluarkan oleh Accounting and Auditing Organization for Islamic Financial Institutions (AAOIFI) yang berpusat di Manama Bahrain dan kalau kita kaji lebih dalamlagi ternyata standar ini masih beranjak dari kerangka akuntansi konvensional. Hal ini wajar karena disiplin akuntansi Syariah sebagai ilmu yang sudah mapan belum bisa terwujud sehingga berbagai paradigma masih tetap menggunakan konsep akuntansi konvensional yang dinilai belum sepenuhnya seirama dengan sifat dan nlai-nilai syariah yang diyakini.

Pada tanggal 1 Mei 2002 secara resmi Dewan standar Akuntansi Keuangan telah megeluarkan PSAK No 59 yang terdiri dari :

1. Kerangka dasar penyusunan dan penyajian laporan keuangan bank syariah 
AlFikra: Jurnal Iliah Keislaman, Vol. 8, No. 1, Januari-Juni 2009

2. Pernyataan Standar Akuntansi Keuangan (PSAK) akuntansi keuangan syariah.

Yang pertama memberikan kerangka dasar dalam menyusun dan menyajikan laporan keuangan bank syariah sedangkan yang kedua merupakan standar teknis dalam pencatatan, penyajian, pelaporan, pengungkapan, pengakuan segala transaksi yang berkaitan dengan kegiatan keuangan suatu bank syariah.

Selama ini penyusunan laporan keuangan bank syariah menggunakan PSAK No. 38 yaitu standar akuntansi keuangan untuk perbankan konvensional, yang tentunya tidak terlalu pas digunakan oleh perbankan syariah meskipun dengan melalui penyesuaian berbagai istilah disana sini. Karena sebagaimana diketahui bahwa laporan keuangan yang disusun sangat tergantung pada jenis industri serta aturan lain yang berkaitan dengan industri itu sediri. Ini berart bahwa aturan Bank yang masih "comot sana comot sini” juga akan mempengaruhi standard dan bentuk laporan keuangannya, sehingga lahirnya standar akuntansi syarah ini perlu disyukuri karena hal in merupakan salah satu instrumen pendukung eksistensi dan perkembangan lembaga perbankan syariah di Indonesia. Meskipun demikian, kita juga sangat menyadari bahwa pada standar yang saat ini diberlakukan tersebut masih perlu adanya berbagai penyempurnaan dan pengkajian lebih lanjut, demi terwujudnya standar akuntansi yang betul-betul berdasarkan syariah.

Demikian juga mengenai industri perbankan Islam itu sendiri masih banyak hal yang harus dikaji ulang. Terlepas dari itu semua PSAK ini sudah harus berlaku sejak periode pembukuan 1 januari 2003. Tugas akademisi tentunya adalah melakukan upaya secara terus menerus untuk melengkapi perangkat akuntansi syariah secara menyeluruh dan merupakan derivasi dari syariat itu sendiri, yang dijabarkan dalam konsep hidup, konsep sosial, konsep ekonomi, dan akhirnya konsep bisnis dan konsep akuntansi syariah.

Selain dari pada hal diatas, perkembangan perbankan syariah ini tentunya juga harus didukung oleh sumber daya insani yang memadai, baik dari segi kualitas maupun kuantitasnya. Namun, realitas yang ada menunjukkan bahwa masih banyak sumber daya insani yang selama ini
Nurhasanah, Akuntansi Syariah di Indonesia...

terlibat di institusi syariah tidak memiliki pengalaman akademik maupun praktis dalam Islamic Banking. Tentunya kondisi ini cukup signifikan mempengaruhi produktivitas dan profesionalisme perbankan syariah itu sendiri. Inilah yang memang harus mendapatkan perhatian dari kita semua, yakni mencetak sumberdaya insani yang mampu mengamalkan ekonomi syariah di semuaa lini karena sistem yang baik tidak mungkin dapat berjalan bila tidak didukung oleh sumber daya insani yang baik pula.

\section{Kesimpulan}

Cerahnya masa depan ekonomi dan kegiatan keuangan syariah bergantung pada kemampuan sumber daya manusia (muslim) baik ilmuan maupun praktisi dalam upaya mereka untuk melepaskan diri dari ketergantungan mereka pada sistem akuntansi konvensional dalam perhitungan, pencatatan dan pembukuan akuntansi dan segera dapat menemukan sistem akuntansi syariah yang benar-benar berbasis pada tuntunan dan tuntutan syariah. Upaya kearah pencarian format akuntansi syariah nampak begitu antusias terutama dilakukan oleh orang-orang yang berada pada lembaga-lembaga yang terkait dengan keuangan syariah seperti di BI dan Ikatan Akuntan Indonesia, selain juga para akademisi. Cepatnya kedua lembaga ini mengeluarkan PSAK sekalipun belum sepenuhnya berbasis pada tuntutan syar'i mengindikasikan antusiasme dan respon positif mereka terhadap perlunya akuntansi syariah yang berbeda dari akuntansi konvensional. Namun demikian, jika para praktisi perbankan dan lembaga keuangan syari'ah lainnya masih didominasi oleh sumber daya manusia yang tidak memiliki latar belakang keilmuan ekonomi syariah, hambatan dari sisi praktis masih akan terlalu besar disamping lemahnya respon mereka terhadap kasus-kasus praktis di lapangan yang akan dapat dicarikan jalan keluarnya oleh para pakar dan akademisi, menjadikan proses menuju ditemukannya sistem akuntasi syariah bisa terhambat. Selanjutnya sikap profesionalisme para pelaku perbankan dan lembaga keuangan syariah yang diharapkan akan menjadi faktor penentu berkembangnya sistem keuangan syariah. 
AlFikra: Jurnal Iliah Keislaman, Vol. 8, No. 1, Januari-Juni 2009

Bibliografi

Adiwarman A. Karim, Bank Islam Analisis Fiqih dan Kenangan, (Jakarta: Rajawali Pers, 2007)

Dillard, Jesse. F, Accounting as Critical Social Science, Accounting Auditing Accountability Jornal, 1991

Iwan Triyuwono dan MJR. Grafikkin, Shariate Accounting An Ethical Instruction of Accounting Knowledge, (New York City: t.p., 1996)

Iwan Triyuwono, Mohammad As'udi, Akuntansi Syari'ah, Jakarta: Salemba Empat, 2001)

Littleton, A.C, Social Accounting, (London: George Allen \& Alwin, 1974)

M. Akhyar Adnan, Akuntansi Syari'ah Arah, Prospek dan Tantangannya, (Yogyakarta: UII Press, 2005)

Meidwati, "Akuntansi Zakat dan Pengelolaannya di Perusahaan", Jurnal Akuntansi dan Auditing Indonesia, Vol.2, 1998.

M. Luthfi Hamidi, Jejak-jejak. Ekonomi Syariah, Jakarta: Senayan Abadi Publishing, 2003)

Morgan, Gareth, Accounting as Reality Construction: Towards a New Epistemology for Accounting Practice, Accounting, Organization and Society, 1988

Muhammad, Pengantar Akuntansi Syari'ah edisi 2, Jakarta: Salemba Empat, 2005)

Sofyan S. Harahap, Akuntansi Islam, (Jakarta: Bumi Aksara, 1997)

Sofyan S. Harahap, Akuntansi Perbankan Syari'ah, (Jakarta: LPFEUsakti, 2004)

Tricker, R.I, Research in Accounting, (Glaslow: University of Glasgow Press, 1978) 